\title{
Diagnosis of the Skills of the Master's Degree: Case Study at the University Pablo of Olavide
}

\author{
Eva Ordóñez Olmedo ${ }^{*} \oplus$, Miguel Baldomero Ramírez-Fernández² \\ 'Postgraduate Studies Centre (CEDEP), Pablo de Olavide University (Seville), Spain \{eordolm@acu.upo.es\} \\ Educacion and Social Psychology Department, Pablo de Olavide University (Seville), Spain \{mbramfer@upo.es\} \\ Received on 13 May 2017; revised on 16 May 2017; accepted on 19 May 2017; published on 15 July 2017
}

DOI: 10.7821/naer.2017.7.249

(c) BY-NC-ND

\begin{abstract}
The work team of the Postgraduate Studies Centre (henceforth CEDEP) of Pablo de Olavide University (henceforth UPO) has submitted a questionnaire in order to identify the training needs of the directors of the master's degrees which are implemented in The UPO during the academic year 2016/2017. This article aims to analyze how the lessons are planned and how the acquisition of the competencies defined in each master's degree are achieved, in order to assess the current situation and propose solutions for university quality improvement. This research presents a mixed design: quantitative and qualitative non-experimental descriptive through a questionnaire. Further to the study analysis conducted, the need to create a manual of recommended practice to arrange curricula by competencies at the master level is presented, as $62.16 \%$ of the participants reflect a great lack of knowledge about the theoretical description of the competencies classification and $73 \%$ support a complementary material need for the design of the curriculum.
\end{abstract}

KEY WORDS: HIGHER EDUCATION, COMPETENCIES, MASTER'S DEGREE, UNIVERSITY CURRICULUM

\section{INTRODUCTION}

The implementation of the European Higher Education Area (henceforth EHEA) in official university master's degrees warns that the didactic planning of a curriculum can not be restricted to distribute contents to different subjects in a schedule using the European Credits Transfer System (henceforth ECTS) as a counting system of the teaching activity. It is true that they have taken into account this situation and that they have designed working environments which deployinterconnected differential strategies conforming to planning based on competencies (Alvarez -Arregui, Rodríguez-Martín, Madrigal-Maldonado, Grossi-Sampedro, \& Arreguit, 2017). However, university education still requires the improvement of innovative pedagogical processes and scientific-technical development (Moreno-Murcia, Silveira, \& Belando, 2015).

Designing a curriculum should start with necessary training on competencies by the persons in academic positions on the master's degrees as agreed in the Bologna Declaration (1999). The competencies to be achieved in each master's degree must subsequently be established. The planning of each module, composed

*To whom correspondence should be addressed:

Pablo de Olavide Univertsity.

Ctra. Utrera km 1 CP: 41013 Seville of one or more subjects, requires a suitable teaching-learning methodology, as well as evaluation criteria and systems which verify its development for an appropriate acquisition. That is why a competency-based training model, where graduates build up their knowledge and achieve more complete professional and personal training (Fernández-Jiménez, Polo, \& Fernández-Cabezas, 2017), is defended. Thus, some teacher and student's working modalities and methodologies, which are adequate for achieving the competencies and are proposed as learning goals (De Miguel, 2006), should be designed.

Accordingly, a questionnaire has been launched by the CEDEP in order to detect the training needs of the persons in academic positions on the master's degrees implemented at the UPO in the academic year 2016/2017.

The research study carried out aims to identify the structure of the current curricula of the official university masters' degree submitted to verification (subject to verification?), to improve technical and academic advice on competencies given to the academic commissions.

This article analyzes how teaching is planned; focusing specifically on how the acquisition of the competencies defined in each master's degree are guaranteed, in order to start from the current reality and to propose solutions for the improvement of future verification reports and university quality. Therefore, the question to be answered is: are university teachers trained to plan and teach a curriculum based on competencies?

\section{CONCEPTUALIZATION}

The concept of competence originates from the business environment, but for several decades it has been used in the academic world (Aguaded-Gómez \& Pérez-Rodríguez, 2012). In spite of the ambiguous and contradictory meanings attributed to this term, conducting a review of the most relevant contributions in this field is absolutely necessary.

The term competence has several meanings and nowadays has become a frequently discussed concept among the different professionals of Higher Education (Ruiz, Rubia, Anguita, \& Fernández, 2010). This polysemy of meanings can give rise to free interpretations which could be due to the fact that in the documents developed by the framework of the EHEA, the term is not correctly conceptually delimited (Angulo, 2008). This author points out that in the official documents (Sorbonne Declaration, Bologna Declaration, Prague Communiqué, Berlin Communiqué, Bergen Communiqué), it is referred to as competent authorities; as increasing competitiveness but not as competencies as it has 
recently been extended according to personal, professional, educational and contextual interests in which they are to be used (Perrenoud, 2004; Zabala \& Arnau, 2007). Following Westera (2001)'s words, the competence construct is differently defined in many studies and the debate about its own definition continues.

\subsection{Competencies}

According to Zetina, Magaña and Avendaño (2017), competence in Higher Education is synonymous of qualification, since it gives a professional vision, a training to the students that enables them to put into practice their abilities, skills and knowledge required by the master's degree for which they should be competent.

Likewise, Posada (2004) states that the concept of competence is quite broad, since it integrates aspects such as knowledge, potential, ability, skills, practice and action of different kinds (personal, collective, affective, social, cultural) in different learning and teaching scenarios.

The executive summary elaborated by the Organization for Economic Cooperation and Development under the DeSeCo (Definition and Selection of Competencies) Project also indicates that "competence is more than knowledge and skill. It involves the ability to face complex requirements, drawing on knowledge and mobilizing psychosocial resources (including skills, abilities and attitudes) in a particular context" (OECD, 2006, p. 3).

Other authors consider competencies as capacities that encompass knowledge, know-how and knowing how to be which must be developed and kept up-to-date in order to face reality from the initial training (Martínez, 2009). Therefore, several authors agree that competencies are made up by the linkages of knowledge, where the conception of the four knowledges are articulated: being, knowing, doing and living together (Cabrera \& González, 2006; Larraín \& González, 2005).

Consequently, competencies are considered to be a synthesis of acquired knowledge, skills and attitudes. These are developed from integrative learning experiences in which knowledge and skills interact in order to give an efficient response to the task being performed. Demonstrations involve the application of learned skills in specific contexts.

Thus, Suárez (2005) points out that educating in competencies means educating in knowledge, directing them towards building people up in a broad and integral sense. That is why establishing the foundations and the satisfactory disciplinary deepening to ensure both personal and intellectual development develop in harmony with the social demands and the labor market are necessary (Tejada \& Ruiz, 2016).

Finally, several references on the topic of competencies in the field of education can be found since the mid-1990s in expressions such as competency-based training, curricula established in competence-based approaches, as an alternative option to improve the academic training processes at basic education level, of the middle technician and professional with studies in Higher Education (Díaz, 2006).

\subsection{Competencies formulation}

Beyond the conceptual domain, as already mentioned, reaching an agreement on a competency profile developed in the university context does not seem to be a simple task. This section outlines the necessary parameters for competence formulation, support for the organization of curricula in Higher Education, specifically in postgraduate degrees at official university master's level.

Perrenoud (2004) makes explicit that competencies formulation is not an objective disposition, but it is a set of theoretical and ideological options and, therefore, leaves great room for interpretation.

Training for competencies provides a management and development approach to lifelong learning in which learning is learned, transforming the reality in which one is immersed is tried, adapting to social, productive, economic and technological changes (Hernández, Martínez -Clares, Martínez-Juárez, \& Monroy, 2009).

As a summary, the following definition of competence is used as reference in future headings. It is used by the Directorate for Evaluation and Accreditation (henceforth DEVA) of the Andalusian Knowledge Agency:

The set of knowledge, skills, and attitudes acquired or developed through coordinated formative experiences. These have the purpose of achieving functional knowledge which responds efficiently to a task or problem of daily and professional life, requiring a teaching-learning process (DEVA, 2016, p. 46).

Therefore, functional knowledge would be the learning outcomes derived from competencies.

\subsection{Competencies in Higher Education}

Prior to the EHEA institutionalization, curricula were organised by objectives, taking into account that these are intentions and purposes which serve as a reference to select training activities and contents for each subject. Through them, the formative process is defined. Therefore, they refer to the discipline content which was taught and they were directly related to the evaluation criteria (Merida \& García, 2005).

On the other hand, the competence-based curriculum structure entails a higher level of generality than that by objectives. Starting from a hierarchical level, first the basic competencies must be established. These are determined in an equitable and common way at a master's level and they cannot be modified, but they are compulsorily acquired at the postgraduate level, as established by the Spanish Qualification Framework for Higher Education (in Spanish, MECES) (MEC, 2011).

It should be pointed out that the general competencies, referring to the degree capacities as a whole, are related to behaviours and attitudes of different fields of knowledge, and can be generalised for most curricula, although with a different incidence and contextualized in each degree (Ordóñez, Caballero, \& López-Meneses, 2016).

On the other hand, specific competencies are taken into account. They determine the type of graduated professionals who want to train. They are particularly applied to each discipline, depending on the field and branch of study that each master's degree has established. They give identity and coherence to any degree (Ordóñez, Ramírez, \& Rey, 2016).

Finally, identifying transversal competencies common to any master's degree in the same university is necessary. These are not associated to specific modules, but to the way of presenting and focusing any module in particular and the curriculum in general in order to lead to the acquisition of the other types of competencies. They intend to entirely train citizens. Following this hierarchy in a competency-based curriculum, the planning and the development of teaching, facilitating transversal spaces of connection between disciplines, are guaranteed.

\section{MATERIAL AND METHOD}

In order to answer the question raised in this research, a mixed design was chosen: Quantitative and qualitative non-experimen- 
tal descriptive using a questionnaire (McMillan \& Schumacher, 2005). This type of study is most appropriate when the field of educational research is given in a real context (Lozada \& Lopez, 2003), since it offers the possibility of knowing, analyzing, discovering and describing reality (Roig, Mengual-Andrés, \& Suárez, 2014).

The questionnaire presents Krippendorff (1990)'s content analysis methodology, based on data obtained through questionnaires addressed to the persons with academic position from the master's degrees. Reproducible and valid inferences, which can be applied in context by means of special procedures for the processing of scientific data, are obtained. The items statement and the questionnaire format followed the guidelines marked by Moreno, Martínez and Muñiz (2004).

Content analysis was identified as the most appropriate research methodology for gathering information because it reveals the interests of a person, group or community (Hernández, Fernández Collado, \& Bautista, 2000). This qualitative technique provides an objective, systematic and quantitative description of the manifest content of communication (Berelson, 1952). According to Stone, et al. (1966), the questionnaires contents will be analyzed and inferences, which will be identified in a systematic and objective way, certain characteristics specified within the answers, will be raised.

This analysis technique has a major application in education (Stone, Dunphy, Smith, \& Ogilvie, 1966) and in monitoring the development of academic studies (Berelsol, 1952). Therefore, this methodology is reinforced by our research.

The criteria on the quality of content analysis, according to Krippendorff (1990), are based on analysis validity and reliability.

The importance of reliability stems from the security it offers concerning the data being obtained regardless of the event, instrument or person who measures it. Consequently, reliable data is that that remains constant in all variations from the measurement process. In this case, reliability has been measured with the Cronbach's Alpha.

The reliability coefficients calculated on each of the questions exceeded 0.8 , indicating a high level of reliability in coding.

Reliability, according to Krippendorff (1990), establishes limits to the potential validity of the research results, but it does not guarantee the results validity.

\subsection{Participants}

The population of this research is composed of persons with academic position from UPO official master's degrees $(\mathrm{N}=157)$. The sampling used $(n=59)$ has been non-probabilistic. It is the most frequent technique in educational research, since the researcher selects a representative sample under study on the basis of knowledge (McMillan \& Schumacher, 2005).

Table 1 shows a breakdown of academic positions by sex, $47.46 \%$ belong to men and $52.54 \%$ to women; among these subjects, $57.63 \%$ have the position of management or co-management of the master's degree, $30.50 \%$ are members of the coordination and $11.87 \%$ are quality managers.
Another important characteristic of the sample is to highlight the typology of the university master's degree, that is to say, $5.40 \%$ belongs to inter-university masters', coordinated by the UPO, and $2.70 \%$ are master's degrees jointly shared with other universities and coordinated by another university other than the UPO. Finally, it should be pointed out that almost $92 \%$ of the respondents to the survey are members of master's degrees taught and coordinated only by the UPO.

\subsection{Material}

The evaluation process about the present state of the master's postgraduate curricula at the UPO has been carried out through a questionnaire which takes into account different quantitative and qualitative aspects reached after the evaluation of the obtained results.

Competency-Based Study Curricula Assessment Questionnaire (in Spanish, CEPEBEC ${ }^{\circledR}$ ), is registered in the Spanish Patent and Trademark Office with docket no: 3640704. This tool consists of 15 items distributed in three dimensions. They represent different domains of competency-based curriculum planning, the study interest, and a set of sociometric data.

\section{A. Diagnostic dimension:}

This section establishes 5 multiple response items and 1 free response item. Item 1 demonstrates, in its first response, the planning of an objective-based curriculum. The second answer shows the implementation of a competency-based curriculum, and the third raises an objection of ignorance of the matter.

Item 2 intends to demonstrate that educational professionals are aware of the concept of competence, and typifies the two remaining answers as incorrect.

The third item focuses on the competencies typology. Once again, the first answer does not show any relation to the competency-based curriculum structure. The second objection is based on the objectives typology and, finally, the third answer shows the ideal classification of competencies.

Item 4 corresponds to an open question, a free response. The intention is determining if the persons of academic positions of the official master's degrees correctly formulate a competence, taking into account the three fundamental aspects that it must contain and the syntactic procedure of the same. Therefore, users' responses have been classified into three categories, following Berelson's (1967) recommendations. The selected categories were exhaustive (until the exhaustion of the whole text) and exclusive, taking into account that the same element of the content cannot be randomly classified into other categories (Noguero, 2002).

In this way, the answers are classified according to the exclusive and exhaustive wording of the competence exposed by the users. Thus, they are typified with these responses in:

- Type 1: Being aware of the theory or cognitive process, for example, the ability to..., with a content to rely on the discipline context. Besides, a context depending on the master's degree.

Table 1. Distribution and participation by sex and academic position

\begin{tabular}{lrrrrr}
\hline \multicolumn{1}{c}{ Sex } & Management & Coordination & Quality management & Porcentaje & \% Design participation \\
\hline Male & 21 & 6 & 1 & 28 & $45,76 \%$ \\
Female & 13 & 12 & 6 & 31 & $25,42 \%$ \\
\hline
\end{tabular}


- Type 2: Slight deficiency in the theory. It exposes, at least, one criterion (cognitive process / content / context).

- Type 3: Ignorance of the theory. It shows an answer that cannot be classified in any of the types previously described, due to ignorance on the subject matter.

The fifth question determines whether users are aware of the characteristics of the different types of competencies, as mentioned in the section devoted to the organization of curriculum in Higher Education, where the difference between basic, general, specific and transversal competencies is shown.

Item 6 of this section questions how the evaluation system has been described in each master's degree; the first response is the ideal one when the master's degree curriculum is based on competencies, the second one when structured on objectives and the third response affirms a lack of knowledge about the topic.

\section{B. Study interest dimension:}

This dimension is composed of a dichotomous item (yes / no), which is equivalent to the seventh question in the survey. It measures the need to propose a recommendations guide. Item 8 (free response) contributes to a request for help or suggestion to improve the curriculum approach.

\section{Sociometric data dimension:}

The sociometric data is composed of five dichotomous items which reveal the macro-area belonging to the concerned population based on DEVA criteria: gender perspective, academic position, participation in curriculum design and the typology which defines its master's degree (inter-university or not).

\subsection{Methodology}

The CEPEBEC ${ }^{\circledR}$ questionnaire was outlined during the month of June 2016 and on July the 7th, a draft which consists of 13 items is issued. This instrument was reviewed and validated by several experts from Eduinnovagogía HUM-971 research group, after having been previously studied by CEDEP's technical staff - with a decade of experience in offering advice to academic commissions in the verification process - by the master's and PhD's area director, and by a member of the Postgraduate and Ongoing Training Vice-Rectorate.

Among the contributions, the field variable of study of the master's degree was incorporated into the draft, according to the criterion established by the DEVA, since this data provides information on other master's degrees in the same area structured according to competencies. Similarly, the inter-university master's variable could bring significant differences concerning the coordination of master's degrees.

Once the final questionnaire in electronic version was created and after a second exhaustive review, it was disseminated through the Limesurvey platform. The questionnaire was sent to subjects twice, the first of which was done in mid-September 2016, and the second one as a reminder a month later.

The Limesurvey application is a web services platform for online survey management. It is a multilingual tool developed in Open Source and it allows the definition of surveys related to competency-based curriculum planning.

With the SPSS 23.0 (2014) software, item discrimination analysis (item-corrected correlation), reliability (internal consistency coefficient) and construct validity were performed, the latter being performed using a principal component factor analysis with varimax rotation.

\subsection{Results}

The following section presents the results of the research study. First, different tables that break down the frequencies and percentages of responses to the items of paragraph CEPEBEC ${ }^{\circledR}$ diagnostic questionnaire are shown.

Table 2. Curriculum design

\begin{tabular}{lrr}
\hline \multicolumn{1}{c}{ Item 1 } & f & \multicolumn{2}{c}{$\%$} \\
\hline (1.a) Answer & 9 & $15,25 \%$ \\
(1.b) Answer & 29 & $49,15 \%$ \\
(1.c) Answer & 21 & $35,59 \%$ \\
Total & 59 & $100,00 \%$ \\
\hline
\end{tabular}

Table 3. Competency concept

\begin{tabular}{lrr}
\hline \multicolumn{1}{c}{ Item D2 } & f & \multicolumn{2}{c}{$\%$} \\
\hline (2.a) Answer & 10 & $16,95 \%$ \\
(2.b) Answer & 7 & $11,86 \%$ \\
(2.c) Answer & 42 & $71,19 \%$ \\
Total & 59 & $100,00 \%$ \\
\hline
\end{tabular}

Item 2, as shown in Table 3, is the highest scoring, since 71.19\% of the participants correctly delimit the concept of competencies, as opposed to $28 \%$ of the selection of both incorrect definitions.

Table 4. Competencies typology

\begin{tabular}{lrr}
\hline \multicolumn{1}{c}{ Item D3 } & f & \multicolumn{2}{c}{$\%$} \\
\hline (3.a) Answer & 2 & $3,45 \%$ \\
(3.b) Answer & 24 & $41,38 \%$ \\
(3.c) Answer & 32 & $55,17 \%$ \\
Total & 58 & $100,00 \%$ \\
\hline
\end{tabular}

Besides, Table 4 represents item 3, with $55.17 \%$, which shows the knowledge on the competencies classification. In contrast to the data of $3.45 \%$, which recognizes the exclusive typology of generic competencies and $41.38 \%$, which mentions objectives types, both being equally incorrect.

Table 5. Competencies classification

\begin{tabular}{lcc}
\hline \multicolumn{1}{c}{ Item D5 } & f & \multicolumn{2}{c}{$\%$} \\
\hline (5.a) Answer & 14 & $37,84 \%$ \\
(5.b) Answer & 12 & $32,43 \%$ \\
(5.c) Answer & 11 & $29,73 \%$ \\
Total & 37 & $100,00 \%$ \\
\hline
\end{tabular}

The fifth item reflects a great lack of knowledge concerning the theoretical description of the competencies classification (Table 5). Thus, it shows the count of $37.84 \%$ correct answers versus $32.43 \%$, which argue that the specific competencies are particular to each discipline field. They give identity and consistency to any degree and they do not belong to the general competencies, and $29.73 \%$, which mentions a statement related to transversal competencies and not to specific competencies. 
Table 6. Evaluation system

\begin{tabular}{lcc}
\hline \multicolumn{1}{c}{ Item D6 } & f & \multicolumn{2}{c}{$\%$} \\
\hline (6.a) Respuesta & 15 & $40,54 \%$ \\
(6.b) Respuesta & 9 & $24,32 \%$ \\
(6.c) Respuesta & 13 & $35,14 \%$ \\
Total & 37 & $100,00 \%$ \\
\hline
\end{tabular}

Finally, Table 6 represents the statistics of item 6 , which refers to the assessment system. It is emphasized that $40.54 \%$ of users are aware that learning outcomes should be evaluable and in relation to the competencies exposed in the curriculum. Instead, incorrect answers are established: on the one hand, the option that the evaluation system is established when a curriculum is designed according to the proposed objectives with $24.32 \%$. On the other hand, $35.14 \%$, state that key competencies are established by the MECES as corroborated in the previous question, but a description of the evaluation system, described in the master's degree is not taken into account.

It is important to emphasize, after the analysis of the answers in item 4 , and according to Figure 1, that there are deficiencies in the writing of the competencies by some of the participants.

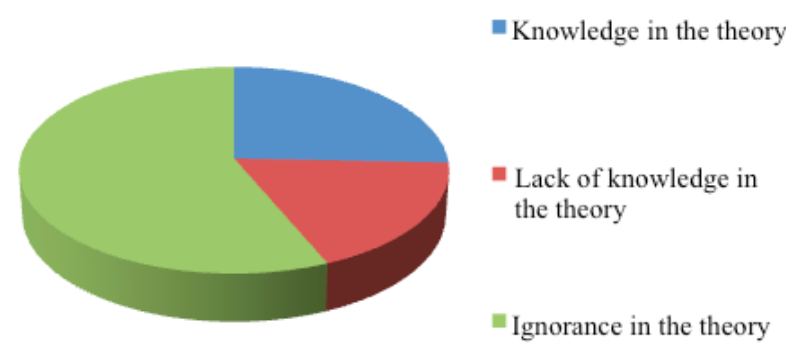

Figure 1. Responses from item $4 \mathrm{CEPEBEC}^{\circledast}$

Following the qualitative analysis of the study, item 8 shows that $64.86 \%$ of users do not present any help or suggestion, whereas $35.14 \%$ of participants propose some important suggestions in order to rectify the users' requests while the project is being carried out in the CEDEP, as shown in Table 7.

Table 7. Suggested users provided by the questionnaire in item 8

\begin{tabular}{cl}
\hline Users & \multicolumn{1}{c}{ Answers } \\
\hline 34 & $\begin{array}{l}\text { It would be advisable to have documentation on different } \\
\text { assessment systems. }\end{array}$ \\
\hline 50 & $\begin{array}{l}\text { Academic commissions should be trained in the design of } \\
\text { new training plans and in the elaboration of the existing } \\
\text { curriculum modifications towards practical guidance } \\
\text { rather than from a purely pedagogical point of view. }\end{array}$ \\
\hline 54 and & $\begin{array}{l}\text { Advice on the identification of different competencies, } \\
\text { as well as the definition of training activities, learning } \\
\text { outcomes and evaluation. }\end{array}$ \\
\hline $55 ; 59 ;$ & $\begin{array}{l}\text { I am especially interested in going further into assessment } \\
\text { in teaching methodology, as much progress is being made } \\
\text { and we need to adapt. In terms of suggestions, I propose } \\
\text { the dissemination of a programming model that I have } \\
\text { designed for Vocational Training, which has an impact } \\
\text { because it is a strong curriculum innovation, its effecti- } \\
\text { veness in leading teaching towards the achievement of } \\
\text { learning outcomes and competencies is indisputable. }\end{array}$ \\
\hline
\end{tabular}

67 I would like the university to help finance the investments that some of us make in teacher training. At the moment it does not: it does not give the training, nor does it finance it when you have completed it. It is somewhat reprehensible.

99 The UPO training plans offered and, today, offer assistance in those points.

\section{DISCUSSION}

The results achieved show that university teachers make mistakes when planning and teaching a competency-based curriculum. Besides, they highlight that there are deficiencies in the conceptualization of the competencies. Therefore, this research responds to the main question and proposes the development of a recommendations guide to structure competency-based curriculum.

Although there is a large amount of research surveys on the organization of competency-based curriculum, this is a pioneering study in the UPO. It proposes, as a prospective line, its implementation in other universities in Andalusia, due to the demand for solutions to the problem manifested by the great majority and to the great interest shown to the lead investigator of the group Eduinnovagogía HUM-971 for the treatment made into it.

In terms of limitations, it is noted that $37 \%$ of the respondents did not distinguish answers for certain items. Therefore, this research shows a weakness in this regard.

\section{CONCLUSIONS}

After the verification of the results obtained, the conclusions drawn from the study are presented. The result of user participation concerning the master's degree curriculum design can be a reflection point, since $29 \%$ of the participants in the questionnaire were not involved in its design: the master's degree was implemented and designed before the incorporation of these members to the academic commission. However, this does not justify the confirmed ignorance about the arrangement of competency-based curriculum.

In addition, any users of the Engineering and Architecture macro-area have participated in the questionnaire. This fact demonstrates the uncertainty and the ignorance of competencies by the persons with academic positions in this area. In this regard, the low participation of members of Health Sciences (5.40\%) is also determined. In future research, efficient competencies training for all persons with academic positions in master's degrees offered at the UPO is necessary, and especially for those whose fields are deficient.

Therefore, there is a need to create a guide or handbook of recommendations in order to structure competency-based curriculum at master level, a proposal endorsed by $73 \%$ of surveyed participants. However, from the research group Eduinnovagogía HUM-971 and from the outline of this work by the CEDEP team, further studies and research have been started. This has resulted in the publication of a guide for teachers on the elaboration of competency-based curriculum, intended to improve teacher training and university educational practice, guiding and strengthening graduates professionalization.

According to Mérida and Garcia (2005), much controversy regarding the level of concreteness in which competencies should be developed exists, since the dialectics between the level of generality or the chosen contextualization is highlighted.

In the survey, the requirement for ongoing training for teachers in order to take up the challenge of training the students who require competencies in constant evolution is needed (Cuban, 2001; 
Gisbert \& Lazarus, 2015; UNESCO, 2004; Wilson, Grizzle, Tuazon, Akyempong, \& Cheung, 2011). It is usually shown that teachers have vague references and are contaminated by the still present behaviorism in education, as well as by the famous and limited technicist pedagogy which stemmed from it. Therefore, a review of training curricula currently offered in the UPO as well as an adaptation to the detected needs according to this study are necessary.

In conclusion, university teachers non-rewarded workload is a negative facto, which influences the organization of the competency-based curriculum model (Gónzalez, Archer, \& Hassall, 2014). Therefore, the CEDEP facilitating and minimizing administrative and academic work in postgraduate degrees is required.

\section{REFERENCES}

Aguaded-Gómez, I., \& Pérez-Rodríguez, M. A. (2012). Strategies for media literacy: Audiovisual skills and the citizenship in Andalusia. Journal of New Approaches in Educational Research, 1(1), 22-26. doi:10.7821/naer.1.1.22-26

Álvarez-Arregui, E., Rodríguez-Martín, A., Madrigal-Maldonado, R., Grossi-Sampedro, B. Á., \& Arreguit, X. (2017). Ecosystems of Media Training and Competence: International Assessment of its Implementation in Higher Education. Comunicar, 25(51), 105. doi:10.3916/C51-2017-10

Angulo, J. F. (2008). La voluntad de distracción: las competencias en la Universidad. In J. Gimeno Sacristán (Ed.), Educar por competencias, ¿qué hay de nuevo? (pp. 176-205). Madrid: Morata.

Berelson, B. (1967). Content Analysis. Lindzey: Handbook of social psychology. New York: Lindzey.

Bolognia Declaration. (1999). Declaración conjunta de los Ministros Europeos de Educación reunidos en Bolonia. Retrieved from http://www.educacion.gob.es/ boloniaensecundaria/img/Declaracion_Bolonia.pdf

Cabrera, K., \& González, L. (2006). Currículo universitario basado en competencias. Barranquilla, Colombia: Ediciones Uninorte.

Cuban, L. (2001). En Busca de la Utopía: un siglo de reformas en las escuelas públicas. Secretaría de Educación Pública, Subsecretaría de Educación Básica y Normal, Dirección General de Materiales y Métodos Educativos.

De Miguel, M. (2006). Métodos y modalidades de enseñanza en la educación superior. In M. de Miguel (Ed.), Metodologías de enseñanza y aprendizaje para el desarrollo de competencias. Madrid: Alianza Editorial.

Díaz, A. (2006). El enfoque de competencias en la educación: ¿Una alternativa o un disfraz de cambio? Perfiles educativos, 28(111), 7-36.

Dirección de Evaluación y Acreditación Andaluza (2016). Procedimiento para la Verificación de Títulos Oficiales (Grados y Máster). DEVA.

Fernández-Jiménez, C., Polo, M. T., \& Fernández-Cabezas, M. (2017). Aplicación de la autoevaluación en una experiencia de Aprendizaje Basado en Problemas con alumnado de educación en asignaturas relacionadas con la discapacidad. Estudios Sobre Educación, 32, 73-93. doi:10.15581/004.32.73-93

Gisbert, M., \& Lázaro, J. L. (2015). Professional development in teacher digital competence and improving school quality from the teachers' perspective: a case study. Journal of New Approaches in Educational Research, 4(2), 115-122.

González González, J. M., Arquero Montaño, J. L., \& Hassall, T. (2014). Consolidación de la formación por competencias en la universidad española: Estudio de un caso. Educación XX1, 17(2), 145-168. doi:10.5944/educxx1.17.2.11483

Hernández, R., Fernández, C., \& Bautista, P. (2000). Metodología de la investigación. México: Mc Graw Hill.

Hernández, F., Martínez-Clares, P., Martínez-Juárez, M., \& Monroy, F. (2009). Aprendizaje y competencias: Una nueva mirada. Revista Española de Orientación y Psicopedagogía, 20(3), 312-319.

Krippendorff, K. (1990). Metodología de análisis de contenido. Teoría y práctica. Barcelona: Paidos.

Larraín, A., \& González, L. (2005). Formación universitaria por competencias. Seminario Internacional CINDA. Currículo Universitario basado en Competencias. Universidad del Norte, Barranquilla, Colombia.

Lozada, J., \& López, R. (2003). Métodos de investigación en ciencias humanas y sociales. Madrid: Thomson.

McMillan, J. H., \& Schumacher, S. (2005). Investigación educativa. Madrid: Pearson-Adisson Wesley.

Martínez-Sánchez, A. (2009). Las competencias especificas en el título de Grado de Educación Infantil (Unpublished doctoral dissertation). Granada, University of Granada. Retrieved from: http://hera.ugr.es/tesisugr/18580713.pdf

Mérida, R. (2006). La convergencia europea y la formación universitaria en competencias para la docencia en educación infantil. Revista de Educación, 341, 663-686.
Mérida R., \& García M. M. (2005). La formación de competencias en la Universidad. REIFOP, 8(1). Retrieved from http://www.aufop.com/aufop/revistas/ indice/digital/114

Ministerio de Educación, Cultura y Deporte. (2011). Real Decreto 1027/2011, de 15 de julio, por el que se establece el Marco Español de Cualificaciones para la Educación Superior. Boletín Oficial del Estado, 185, de 3 de agosto.

Moreno, R., Martínez, R. J., \& Muñiz, J. (2004). Directrices para la construcción de ítems de elección múltiple. Psicothema, 16, 490-497.

Moreno-Murcia, J. A., Silveira Torregrosa, Y., \& Belando Pedreño, N. (2015). Questionnaire evaluating teaching competencies in the university environment. Evaluation of teaching competencies in the university. Journal of New Approaches in Educational Research, 4(1), 54-61. doi:10.7821/naer.2015.1.106

Noguero, F. L. (2002). El análisis de contenido como método de investigación. Revista de Educación, 4(2002), 167-179.

OCDE (2006). La definición y selección de competencias clave. Resumen ejecutivo. 1-20. Retrieved from http://www.deseco.admin.ch/bfs/deseco/en/index/03/02. parsys.

Ordóñez, E., Ramírez, M. B., \& Rey, D. (2016). Recomendaciones para el diseño de un plan de estudios basado en competencias. San Juan (Puerto Rico): UMET Press/Universidad Metropolitana/Sistema Universitario Ana G. Méndez.

Ordóñez, E., Caballero, G., \& López, E. (2016). Propuesta de mejora en el ámbito competencial de los planes de estudio de postgrado. Revista Educativa Hekademos, 21, 44-54.

Perrenoud, P. (2004). Diez nuevas competencias para enseñar. Barcelona: Graó.

Posada, R. (2004). Formación superior basada en competencias, interdisciplinariedad y trabajo autónomo del estudiante. Retrieved from http://www.rieoei.org/ edu_sup22.htm

Roig, R., Megual-Andrés, S., \& Suárez, C. (2014). Evaluación de la calidad pedagógica de los MOOC. Profesorado: Revista de curriculum y formación del profesorado, 18(1), 27-41.

Ruiz, I., Rubia, B., Anguita, R., \& Fernández, E. (2010). Formar al profesorado inicialmente en habilidades y competencias en TIC: perfiles de una experiencia colaborativa. Revista de Educación, 352, 149-178. Retrieved from http://www. mecd.gob.es/dctm/revista-de-educacion/articulosre352/re35207.pdf?documen$\mathrm{tId}=0901 \mathrm{e} 72 \mathrm{~b} 812342 \mathrm{c} 4$

Stone, P. J., Dunphy, D. C., Smith, M. S., \& Ogilvie, D. M. (1966). The genere inquirer: A computer approach to content analysis. Cambridge: MIT Press.

Suárez, B. (2005). La formación en competencias: un desafio para la educación superior del futuro. Retrieved from http://www.uis.edu.co/portal/doc_interes/ documentos/Formacion_por_Competencias_Suarez_Arroyo.pdf

Tejada, J., \& Ruiz, C. (2016). Evaluación de competencias profesionales en Educación Superior: Retos e implicaciones. Educación XX1, 19(1), 17-38.

Tobón, S. (2005). Formación Basada en Competencias. Pensamiento complejo, diseño curricular y didáctica. Bogotá: Ecoe.

UNESCO (2004). Educación para Todos en América Latina: Un objetivo a nuestro alcance. Informe Regional de Monitoreo de Educación para Todos (2003) (Report). Santiago de Chile.

Westera, W. (2001). Competences in education: a confusion of tongues. Journal of Curriculum Studies, 33(1), 75-88. doi:10.1080/00220270120625

Wilson, C., Grizzle, A., Tuazon, R., Akyempong, K., \& Cheung, C. K. (2011). Alfabetización Mediática e informacional: Curriculum para profesores. Retrieved from http://repositorio.minedu.gob.pe/handle/123456789/4586

Zabala, A., \& Arnau, L. (2007). 11 ideas clave. Cómo enseñar aprender y enseñar competencias. Barcelona: Graó.

Zetina, C. D., Magaña, D. E, \& Avendaño, K. C. (2017). Teaching Research competence: a challenge in Educational management. Revista Cientifico Pedagógica Atenas, 37(1), 1-14.

How to cite this article: Ordóñez, E., \& Ramírez, M. B. (2017). Internet and people with intellectual disability: an approach to caregivers' concerns, prevention strategies and training needs. Journal of New Approaches in Educational Research, 6(2), 159-164. doi: 10.7821/ naer.2017.7.249 